\title{
EFEITOS E SIGNIFICADOS DAS EXPERIÊNCIAS PARTICIPATIVAS
}

\author{
HEREDIA, Beatriz et al. (Org.). \\ Política, governo e participação popular: \\ conselhos, orçamento participativo e outras experiências. \\ Rio de Janeiro: 7 Letras, 2012. 224p.
}

POR

\section{Luciano Padilha dos Prazeres ${ }^{1}$}

A obra Política, Governo e Participação Popular: conselhos, orçamento participativo e outras experiências apresenta ao leitor análises detalhadas de processos sociais comumente vistos como ambíguos na literatura corrente. Deslocando-se das prescrições de transformações da democracia ou da esfera pública e das análises da efetividade e eficiência de políticas públicas promotoras da participação social, os autores, antes, procuram compreender os significados e efeitos de experiências rotuladas como similares, tais como conselho de saúde, orçamento participativo, entre outras. Desse modo, a obra complementa preocupações anteriores desenvolvidas principalmente em torno do Núcleo de Antropologia da Política, núcleo de pesquisa vinculado ao Museu Nacional e à Universidade Federal do Rio de Janeiro, no qual as atividades sociais tidas como políticas atraíam a atenção dos pesquisadores.

Partindo dos resultados da pesquisa "Gestão Municipal e Formas de Participação Popular", empreendida no início dos anos 2000 e financiada

\footnotetext{
1 Doutorando em Antropologia pela Universidade Federal Fluminense, Brasil. padilha_cso@yahoo.
} com.br 
pela Fundação Ford, os autores trazem ao leitor olhares distintos sobre a participação da população nos processos de tomada de decisões. Os autores, Beatriz Maria Alasia de Heredia, Odaci Luiz Coradini, Marcos Otavio Bezerra, Irlys Alencar Firmo Barreira e Moacir Palmeira, exploram, nos casos pesquisados, os mecanismos ou instrumentos de participação popular acionados pelas administrações municipais observando-as como "experiências participativas". Exploram-nas através dos significados das práticas e representações dos segmentos sociais, políticos e entidades envolvidos notando, preliminarmente, a diversidade de ideários de participação popular.

Cada autor toma casos específicos para análise: Beatriz Heredia analisa o Conselho Municipal de Saúde de Jurema e o Orçamento Participativo de Cascatas ambos no Rio Grande do Sul; Odaci Coradini, os Conselhos Regionais de Desenvolvimento e o Orçamento Participativo Estadual naquele mesmo estado; Marcos Bezerra, o Conselho Municipal das Associações de Moradores de Pargo e o Conselho Municipal de Saúde de Sereno no estado do Rio de Janeiro; Irlys Barreira toma para análises o Conselho Comunitário Municipal de Santa Mariana, o Conselho Municipal de Desenvolvimento Sustentável de Sandoval e o Orçamento Participativo de Paranaí, no estado do Ceará; e Moacir Palmeira analisa os Pólos de Desenvolvimento Rural em Brejo dos Santos, em Pernambuco. Tais localidades são denominadas ficcionalmente e se configuram como municípios de pequeno e médio porte. Embora os cinco artigos que compõem a coletânea tratem de casos singulares, eles podem ser lidos conjuntamente numa ótica que privilegia os aspectos de conflito ou disputas em torno da ideia de participação popular.

Nas análises sobre as experiências participativas os autores consideram as configurações sócio-econômicas de cada localidade e região, as quais implicam o rearranjo sócio-político dos mecanismos de gestão pública bem como a estruturação das relações de poder nas localidades. Desse modo os autores observam a importância relativa de cada conselho e fórum para os atores envolvidos. Por exemplo, enquanto uns detém a "marca de um 
governo", outros são tidos como "simples formalidade". Os mecanismos de gestão pública são explicitados pelos autores como espaços de disputas com maior visibilidade das relações políticas, ou nas palavras dos mesmos, "experiências mais significativas" da participação popular do ponto de vista da administração municipal e da população.

Decorrente do objetivo da pesquisa, qual seja, a compreensão dos significados atribuídos às formas de participação na gestão pública e seus efeitos na organização social local, os autores exploram a diversidade de significados da participação popular conforme a experiência participativa e os segmentos populacionais em questão. Dentre alguns dos significados estão a prática de governo a qual se adensa como "presença em reuniões”, "exercício da cidadania", "acesso a órgãos públicos", como também sob a forma de "cidadania emancipatória", de "participação efetiva", "racionalização do coletivo" e "reuniões da comunidade". Além destes significados, a participação popular associa-se também a noções como "gestão eficiente", "gestão participativa", "governo comunitário", "governo participativo" distinguindo-se, para cada termo, as disputas em torno de formas legítimas de participação. Na forma de princípios, a participação popular se desloca entre a "representatividade" através de determinados segmentos sociais e a "universalização" da participação da população.

Demais aspectos das experiências participativas analisadas são observados com a reconfiguração do papel do governo, do executivo e legislativo municipal, de lideranças, de entidades e segmentos sociais. Os papéis se reconfiguram com operações de rearranjo dos espaços públicos, com a caracterização das demandas e dos modos de intervenção na e da gestão pública. O envolvimento da população ou dos segmentos populacionais contribuem para o redirecionamento das práticas políticas em que se observa certa necessidade de se ouvir as assembleias e o surgimento de novos problemas afora aqueles para os quais os conselhos ou fóruns foram criados. Dentre os efeitos das experiências participativas na organização social, os autores discorrem sobre a própria abertura de espaços 
de participação e representação política; o deslocamento das disputas prévias para estes espaços e irrupção de novos conflitos; a mobilização da participação popular como instrumento de autenticidade e legitimidade de programas de governo, de ações de entidades civis, de partidos políticos e de lideranças bem como a mobilização de ideários de participação como fonte de autoridade. Outros efeitos sociais são remetidos à construção de identidades, de territorialidades, de carreiras políticas e de lógicas sociais a partir da atuação dos atores sociais; remetem às transformações das formas de governo e à reestruturação das relações de poder.

As análises compreensivas e comparativas dos autores contribuem para lançarmos novos olhares para as relações sociais construídas em torno dos mecanismos de gestão pública, bem como para os discursos que acionam as práticas e concepções sobre as experiências participativas. Com estes novos olhares, a "participação popular", antes de se constituir como uma categoria dada, pode ser tomada como eixo fundamental para a observação e compreensão de modos de governo, ao menos, de certa problematização da distinção comum entre "governo" e "sociedade" e de categorias correlativas como participação social, participação civil, participação comunitária. Portanto, o leitor encontra na coletânea subsídios interessantes e perspicazes para a compreensão de experiências participativas cada vez mais recorrentes na administração pública. 